\title{
A Qualitative Study on the Effects of Teacher Attrition
}

\author{
Aminu Aliyu Wushishi (Corresponding author) \\ Faculty of Educational Studies, Universiti Putra Malaysia \\ E-mail: amliyu@yahoo.com \\ Foo Say Fooi \\ Faculty of Educational Studies, Universiti Putra Malaysia \\ Ramli Basri \\ Faculty of Educational Studies, Universiti Putra Malaysia \\ Roslen Baki \\ Faculty of Educational Studies, Universiti Putra Malaysia
}

Received: 04-10- 2013

doi:10.7575/aiac.ijels.v.2n.1p.11
Accepted: 16-11-2013

URL: http://dx.doi.org/10.7575/aiac.ijels.v.2n.1p.11
Published: 31-01-2014

\begin{abstract}
In this study the researchers explored the effects of teacher attrition in Niger state, Nigeria. The study examined how attrition is affecting the educational development of the state from the teachers' perspective. A qualitative method was used with the aim of extracting the inner feelings of the participants regarding the effects of attrition. Five serving teachers were purposively selected. An in-depth interview, non-participatory observation and document analysis were used as means for data collection. The findings discovered; cost implication, increased in workload, poor students' performance and burden on school administration, as the major effects of teacher attrition. The paper therefore recommends that, the state government needs to improve the condition of service of teachers with the aim of reducing the rate of attrition so as to improve the educational standard of the state.
\end{abstract}

Keywords: teacher, teaching, attrition

\section{Introduction}

With the current awareness on the importance of education for national development, the sector is greatly expanding and is growing from strength to strength, thereby becoming one of the greatest social services for almost every nation in the world (Salahu \& Aminu 2010). The rapid growth in education can be seen practically in the huge resources invested in the sector, the ever-multiplying schools, the student's enrolment and the increasing number of staff. This development has added to the complex nature of educational organizations in general and the school system in particular which requires effective and committed teaching staff who will handle the situation.

One of the greatest problem facing many schools in both developed and developing nations is the issue of teacher attrition. Series of researches around the globe have identified the issue of teacher attrition as worrisome. In the US for instance, Ingersoll (2013) identified that every year about $15.7 \%$ of teachers leave the profession to another profession, while $40 \%$ of those teachers sponsored to further their studies are not willing to return back to teaching again. Out of the 3,252 teachers hired by the district of New York between 2010-2011, about 7.8\% left teaching within the first year, while $16.3 \%$ left within the first two years (Mcadoo 2013). The situation is same in UK, about $14.1 \%$ teachers moved out of the profession within their four years of entrance into the profession (Alan \& Pamela 2003).

Developing nations of Africa were not left behind on teacher attrition. In Ghana, about 33,185 teachers abandoned their teaching position to seek for other jobs (Ghana Business News 2013). The rate of attrition is minimal in the south western part of Nigeria with about $10 \%$ of teachers living their profession to other jobs within the first five years of entering into teaching (Okundayo 2010). These findings is similar to that of Poopola (2009) who affirmed that, teacher attrition is less in the South and Western part of Nigeria which fall within the range of 10-15\%. But the rate of attrition is high in the northern part of Nigeria probably because the low level of education and the job opportunities compared to the Southern part of the country. Adamu (2010) described the level of attrition to about $20 \%$ in some parts of the Northern Nigeria. This assertion was supported by Fati (2010) who reported that, over 10\% of teachers leave teaching profession to better jobs within their first three years.

Recent studies have discussed the effects of teacher attrition either on the academic performance of students or on the financial aspects that is involved in addressing the attrition. For example, Bryk and Schneider (2002) discovered that the quality of relationships (trust) that exist between teachers and their students is related to students' achievement and their 
performance, so when the teacher leave the profession the students will be affected academically, although, the authors further states that, the attrition may also affect the students positively because those that will take over in the replacement of the exited teachers may have new ideas that will be beneficial to the students.

\section{Methodology}

To ascertain the effects of teacher attrition from the teachers' perspective, a qualitative method was used in conducting the research. According to Merriam (2009) qualitative research is about understanding peoples' interpretation, their experience and meaning they attributes to certain phenomenon. According to Creswell (2009) a qualitative method is a kind of method in research that is aimed at exploring or understanding the meaning individuals or groups ascribe to a social or human problem. The purpose of qualitative studies is to describe a phenomenon from the participants' points of view through interviews and observations. In qualitative study the intention of the researcher is to listen to the voice of participants or observe them in their natural environments (Field \& Morse, 1992). There are different forms of qualitative research, but case study was selected in conducting this research with the aim of capturing the views of the participants in details.

\subsection{Participants}

The success of every qualitative research counts on the supports from the participants, who are to provide vital information on the research. To achieve this target, five teachers were purposively selected based on their experience in teaching profession. Three out of the five teachers have been teaching for the past twenty years, while the remaining two have more than ten years of teaching experience. The participants were contacted through their principals who suggested their names based on the fact that, they are capable of providing the required information for the success of the research. Two of the participants have Master degrees while the remaining three have Bachelor degrees in different field of study. For confidentiality the participants were reported as Respondents in the study.

\subsection{Data collection}

In qualitative research, the researcher is the instrument unlike in quantitative research where a set of questions are itemised to solicit information. Interview is mainly used to collect data in qualitative research, to be supported by observation, and analysis of relevant documents. This research was also in line with the qualitative protocol. The researchers used interview to obtain their data from the participants. The interview lasted for months and each session took between one hour to two hours respectively. The participants were contacted at their work place in their free periods. A tape recorder was used with the permission of the participants, and at the end of every interview session, before the next session of another interview the researchers transcribed the recorded interview verbatim so as make sure that no single vital information has escaped. The transcribed interview was visited and revisited severally with the aim of forming categories and the same process was adopted until the required themes emerged. Other means of data collection such as; none participatory observation and document analysis were used.

\section{Validity and Reliability}

This is very important in qualitative research. For the sake of establishing validity and reliability in our research, certain qualitative procedure were followed; triangulating different data sources of information by examining evidence from the sources and using it to build a coherent justification for themes. Member checking was also adopted so as to determine the accuracy of the qualitative findings. The final report was taken back to the participants for their observations and to determine whether what they said was accurately reported. And finally, to enhance the accuracy of the account, the researchers consulted a different person outside the jurisdiction of the research who went through the data and commented as well.

\section{Analysis of Result}

Data was analysed based on the themes that emerged from the data collected, as indicated below.

\subsection{Effect on Student's Performance}

All the respondents commented that teacher attrition has effect on students' performance. Below are the opinions of the respondents regarding the effect.

Respondent $\mathbf{D}$ believed that, if students are properly handled by hardworking teachers who know their subject matter very well, the students are likely to understand the subject better and can result to better performance in their exams, but if there are no adequate teachers to teach the students their performance will be low. The respondent added that,

....not to even talk of final year examinations, even at the school internal examinations we use to see changes in performance of students particularly in the subjects where they have shortage of staff especially the experienced ones. The students usually perform better if they have received regular and adequate lesson from their teachers. So from what I observed in my school, I can conclude that teacher attrition can affect students especially their performance in the exams.

Although, Respondent $\mathbf{B}$ believed that there are many factors which can affect students' performance either in examinations or in their academic activities, but the most influential of all the factors is the teacher. He commented 
that, teacher has major role to play on the performance of the students, because he is the one to teach and assess the students to ascertain their level of understanding, if not satisfactory he will then take measures by either re-teaching the topic or adopt another strategy to enable them comprehend.

Respondents A and C shared the same view, citing their school as reference. They testified that the performance of their students has gone down. Respondent $\mathbf{A}$ being the only Mathematics teacher testified that because of the population of the students and the number of classes he handles, it is becoming difficult for him to properly cover the topics for all the classes as expected. Respondent $\mathbf{C}$ is also facing the same problem being the only Accounting teacher, the students are not getting the right attention from him. This was as a result of their population. In summary, the students are not getting the required attention in terms of teaching, and this has great effects on their performance, they added.

\section{Respondent E said,}

The performance of our students is so low, while in some subjects I can say is poor because we are having shortage of staff particularly in science subjects, because most of the staff that read science courses like chemistry, physics and mathematics, have better opportunity of getting another job easily.

\section{Increased workload of serving teachers}

Another finding of this study according to the responses of the respondents was that, teacher attrition increases the workload of the serving teachers. Almost all the respondents commented that when teachers leave the profession, the burden will be added to the serving teachers.

Respondent A stated that, teacher attrition always results to increase in workload because according to him, whenever a teacher leaves the profession and has not been quickly replaced, definitely the position will be vacant. In other words, the class or the subject he/she is taking will have no teacher. So there is the need to urgently add up the teaching responsibilities to the serving teachers, which will be a burden to them because of the increase in the existing workload.

Respondent $\mathbf{C}$ highlighted that, from his discussion with his colleagues who were in other schools, he was made to understand that, almost all the schools are facing the problem of increase in workload as a result of teacher attrition. He further said:

...Although the case is minimal in some subject areas, but is common with other subjects particularly Mathematics, English and some science subjects. The teachers are limited and the rate at which the graduates in the field are joining the profession is low, so you will realize that the few ones that are leaving the teaching profession are adding burden and increasing the workload of the existing teachers. He added that, in several occasions he has heard his principal complaining to the Ministry of Education for more teachers, but no action has been taking to tackle the situations, the only option according to the ministry is that, the principals should continue using their available human resource, so as to keep their schools going.

Respondent E stated that, in some schools where teachers of a particular subject are not enough the principals at times convert those with related qualification to fill the vacuum. He cited an example with his school where a physics teacher was converted to be taking Mathematics as a result of lack of adequate teachers in Mathematics because of attrition. Respondent $\mathbf{D}$ shared an experience on the effects of teacher attrition with particular reference to increase in workload. He stated that:

few years ago, there was one hardworking English teacher who was handling about four classes, the teacher was so dedicated to his teaching job, he later got appointment with the Ministry of Internal Affairs and just left. Unfortunately the school was left with only one English teacher, who was handling some classes already, but with the exit of the other teacher his workload increases. This resulted to a wide gap in the school and increased the serving teacher's workload.

Respondent B concludes that, based on his experience as a teacher who taught in various schools within the state, almost all of the schools in the state has some problems regarding shortage of teaching staff, and this situation according to him is adding more burden to the teachers on ground.

\subsection{Effect on Administration of Schools}

All the participants commented that teacher attrition has effect on the administration of schools. Respondent B commented that, teacher attrition is one of the factors that can affect the administration of the school. He added that in a school where a hard working teacher is given an administrative responsibilities and within a short period of time that teacher leave the teaching profession, definitely another teacher have to be appointed and in most cases the new 
appointed one may not be as experienced as the one that left. He must be guided by the principal before he becomes active in the position. In other words, the smooth administration of the office may have a set back as a result of the attrition.

Respondent A cited an example with his labour master who left teaching after serving for about 20 years. He said:

\begin{abstract}
Mal. Inusa served as a teacher for almost 20years and has been in this school for almost 9 years. He was appointed labour master 7years prior to his new appointment with the Nigeria Prison Service. In fact, he helped a lot in maintaining discipline in this school; students where well behaved and punctual, even teachers respected him. In the administration of this school, he was more important than even the senior master. But after he left, things changed drastically because the man appointed to replace him is not as active as he was, but I know with time he may pick-up. So you can now see how the administrative responsibility of the office was affected."
\end{abstract}

Respondent $\mathbf{C}$ highlighted that, being the exam officer of his school, co-coordinating examinations is becoming difficult for him, since the exit of his exam officer II, he requested severally with the school management but the principal kept telling him to be patient because of shortage of staff and most of the staff on ground has one responsibility or the other. $\mathrm{So}_{2}$ it is not always easy to administer and co-coordinate examinations. He added that not only in the area of school administration, even within them (those teachers with responsibility) things have not been easy for them due to the shortage of staff as a result of attrition.

Respondent $\mathbf{D}$ added that, the principal cannot be everywhere, he has to delegate certain responsibilities to his teachers so as to help him in the co-ordination of the school, but if the teachers are not available, the principal will be left with an option of whether to administratively overload his staff or extend his administrative responsibilities by overworking himself round the clock. Respondent $\mathbf{E}$ concurred with Respondent $\mathbf{D}$, saying that it is not easy for the principal alone to administer a school, he must employ the services of some teachers and if the teachers are appointed and leave job within short period of their appointment, the administration of that school will be affected.

\title{
4.3 Financial Implications
}

Another interesting finding of this study is that, all the participants commented on the financial implications involved as a result of teacher attrition.

Respondent B is with the opinion that, allowing teachers to leave teaching profession has cost implication particularly on the part of government, because they need to invest a lot of money again in recruiting and training of teachers so as to replace those that quitted out of the profession. He added that, recruiting new teachers has process and procedure which has financial implications.

\section{Respondent A said:}

Government is sometimes not considerate, they tend to ignore their responsibilities on teachers by not providing the expected incentives to retain them in the profession, and if the teachers decided to leave the profession to another, they (government) will start to advertise for their replacements which will involve finance, recruitment and training also has financial implication.

Respondent $\mathbf{C}$ disclosed that during their induction training, one of the facilitators told them that, government is spending about 150_million Naira for the recruitment and training of teachers in the state. So if teachers continue to leave, then the government will continue to spend more money on the process and this will not speak well on the government side.

Respondent D concurred with other participants that teacher attrition can result to increase in cost, but further expanded his explanations in relation to the economic situation, saying that;

Nigerian economy particularly the currency is devalued; if you spend N1,000.00k on a particular programme today, in the next two or three years you will have to spend N2,000.00k on the same programme so if teachers are recruited this year and government spend like N10million on the exercise in the next two or three years government would have to double the amount on the same number of teachers.

Respondent $\mathbf{E}$ commented that, government is spending a lot in the area of recruitment and training of teachers, as such they should not always allow teachers to be leaving the profession as a result of their inability to retain them, because the cost they will incur at the end will be of great lost on their side. In addition, he specified that government will have to train new teachers, by hiring the services of resource persons who will train the teachers and make provision on all other expenses that will be involved in the process. 


\section{Discussion}

Majority of the interviewed teachers have expressed that, they observed the performance of their students particularly on the subjects where teachers are inadequate, and they discovered low performance in their examination results, although some of the teachers commented that, there are several factors that can contribute to the low performances of the students but the major of all the factors is teacher. This is because according to them, no matter how well equipped a school is, if there are no teachers to teach, the end result will be negative. This finding is similar to that of Buddin and Zamarro (2009), who conducted their studies among teachers in California to ascertain teacher quality in relation to students' academic success. They examined teacher qualification and students' success on one hand and teacher experience and students' success on the other hand. The outcome revealed that, student achievement was unaffected by whether the teacher has advanced degrees, but students' achievements increases with teacher experience.

Another area touched by the findings of this study, was the issue of cost involved as a result of teacher attrition. All the respondents commented on the financial commitments involved as a result of teacher attrition. This is in line with Nweke and Eads (2007) who conducted their study in Georgia. In reporting the outcome of their study, they analysed that within the year of the research, it cost the state of Georgia almost $\$ 400$ million to replace the teachers lost to attrition. They further commented that if the state had reduced attrition by retaining their teachers with about $35 \%$, the cost of replacing teachers would have been reduced by more than $\$ 136$ million. In addition, Pitsoe and Machaisa (2012) commented on the importance for retaining teachers, that inability to retain teachers will places the education system at risk of lower teacher quality, greater inequity in student opportunities, and increased inefficiency as more funds are diverted to recruiting and training new teachers.

The process of recruiting teachers in any country involves the use of funds, because of the paramount importance of education to the development of every society. In Niger state, Nigeria for example, whenever the government wants to recruit teachers, a lot of money will be spent in both the advertisement, hiring of facilitators to train the teachers and the process of posting. There is no clear evidence on how much the state is spending, but according to what few of the participants said, the government is spending between 150-200million naira. Despite all efforts to get the exact figure from the ministry officials prove abortive, the researchers discovered, the state government is losing a lot of money as a result of teacher attrition.

In every organization there must be a leader who will pilot the affairs of that organization towards the achievement of their goals. In secondary schools, it is the principal that serves as the head who is always assisted by his teachers in running the affairs of the school. In most cases, people with vast experiences in teaching profession are appointed by the principal to help in the administration of the school. The exit of these experienced teachers always constitutes problem to the administration of the schools.

Some of the participants commented on how teachers are playing their roles in the administration of their various schools, how they are working with the principal as a team. Gronn (2002) advocated that, the effectiveness of administration involved team. He added that, the team can achieve what an individual cannot achieve when he operates alone. This is an indication that, administration of school can be affected when a principal form his administrative team and on the process the team breaks as a result of attrition.

All the interviewed teachers mentioned how teacher attrition is causing increase in workload among the serving teachers. Majority of the teachers commented on how the problem affected them and their colleagues. Jude (2008) stated that, the number of teachers leaving the profession is increasing while the rate at which government is replacing them is decreasing. This shows that, if the rate at which teachers are leaving is high and their replacement is low, then definitely the serving teachers will suffer. Yazhuan, Qing and Yugui (2010) conducted their studies in Shaanxi province in China, using 101 chemistry teachers from 15 schools, to ascertain major sources of stress. The result revealed that, workload became the highest source of stress with $34 \%$, while school system has $11 \%$, followed by social treatment and demand with $7 \%$.

Although, this problem is not only peculiar to the study area, some secondary schools in Nigeria had the same problems, as reported by Enaohwo (2010) and Adelabu (2005). Some schools are without adequate teaching staff, students suffers from receiving regular lessons, while some manage their few teachers by overloading them with subjects even outside their specialization (Adelabu 2005).

\section{Conclusion and Recommendation}

Based on the findings of this study, it can be concluded that, teacher attrition has a lot of effects on the study area. The interviewed participants complained on the burden of workload as a result of shortage of teachers and this is making the profession stressful to them. There was also the issue of poor academic performance among students, which is becoming worrisome to both the teachers and the school administrators. The cost implications of teacher attrition is a serious problem as it involves a lot of funds in the recruitment and training of new teachers. The paper therefore recommends that, government needs to improve the condition of services of teachers in the study area so as to curtail the issue of attrition and this will reduce the cost implications of teacher recruitment, reduce the workload as complained by all the participants, and improve the academic standard of the students, which will lead to successful achievement of the educational goals and objectives of the state. 


\section{Reference}

Adamu A. (2010) A Techniques on improving Staff Morale in Public Secondary Schools in Bauchi State. Unpublished Master thesis, Bayero University Kano, Nigeria.

Adelabu M.A (2005) "Teacher motivation and incentives in Nigeria" Retrieved on 4 th October 2011 from www.dfid.gov.uk

Bryk, \& A.S \& Schneider, B. (2002). Trust in schools: A core resources for improvement. New York: Russell Sage Foundation.

Buddin, R., \& Zamarro, G. (2009). Teacher qualifications and student achievement in urban elementary schools. Journal of Urban Economics, 66(2), 103-115.

Creswell, J.W (2009) Research Design Qualitative, Quantitative and Mixed Methods Approaches. Sage publishers: London.

Ekundayo, H.T (2010) Administering Secondary Schools In Nigeria For Quality Output In The 21st Century: The Principals' Challenge European Journal of Educational Studies 2(3), 2010 ISSN 1946-6331

Enaohwo, J. (2010) A study of teacher turnover in selected secondary schools in Bendel state of Nigeria. Nigeria Journal of Teacher Education and Teaching

Fati A.A (2010) Teacher Retention in Secondary School System: A strategy for effective Planning of Education in Minna Metropolis. Unpublished Master thesis, Usmanu Danfodiyo University Sokoto, Nigeria.

Field, P.A., \& Morse, J.M. (1992). Nursing research. The application of qualitative approaches. London: Chapman \& Hall.

Ghana Business News 2013 retrieved on $30^{\text {th }}$ October 2013 from www.ghanabusinessnews.com

Gronn P (2002). Designer leadership: The emerging global adoption of preparation standards Journal of school leadership 12 (5), 552-560

Ingersoll, R. (2013) Why Do Teachers Quit? The Atlantic Magazine retrieved on $10^{\text {th }}$ October 2013 from www.theatlantic.com/education/archive

Jude, W.I (2008) A critique of teacher education in Nigeria: implications for Quality Assurance. Nigerian Journal of Teacher Education and Teaching, 4(1), p 321-329

Mcadoo M. (2013) Teacher attrition up after recession-driven full. United Federation of Teachers retrieved on $17^{\text {th }}$ November 2013 from www.uft.org

Merriam S.B (2009) Qualitative research A guide to design and implementation: Revised and expanded from Qualitative and case study application in education $2^{\text {nd }}$ edition. San Francisco: Jossey- Bas publication.

Nweke, W. C., \& Eads, G. M. (2007). The Cost of Teacher Attrition and Savings from Reducing Teacher Attrition, available at www.gapsc.com/reasearch

Pitsoe, V. J., \& Machaisa, P. R.(2012) Teacher Attrition Catastrophe in Sub-saharan Africa: A Hurdle in the Achievement of Upe, Efa Policy Goals and Mdgs. Science Journal of Sociology \& Anthropology, 2012.

Popoola, A. (2009). Rotten apple: An investigation of the preponderance of unsatisfied teachers in Nigeria. International NGO Journal, 4(10), 441-445.

Salahu M.L \& Aminu A.W (2010) History education for national development. Journal of educational studies, 2(3). pp. 223-232

Yazhuan, L., Qing, Z., \& Yugui, Z.(2010) An investigation into sources of stress among high school chemistry teachers in China. Procedia - Social and Behavioral Sciences, 9(0), 1658-1665. 